\title{
Glenn M. Garcia: Radcases musculoskeletal radiology
}

\section{2nd Editiion, Thieme Verlag, New York, Stuttgart, Delhi, Rio de Janeiro, 2017, 224 pp, 716 figs., 279.0 mm, Hardcover (KT), e-book, EUR (D) 59,99 EUR (A) 61,70 CHF 69,00, ISBN: 978-1-62623- 244-0}

\author{
Alain G. Graftiaux ${ }^{1} \cdot$ Pierre Kehr $^{1}$ \\ Received: 6 May 2018 / Accepted: 20 May 2018 / Published online: 4 June 2018 \\ (c) Springer-Verlag France SAS, part of Springer Nature 2018
}

This book presents 100 radiological cases of examinations but also scanographic with and without arthrography, MRI, echography for which the reader will have to make a diagnosis. For each case the answer is given with the elements to observe on the differential images, diagnoses and the traps. If that were not to be enough in addition 350 case reports can be reached online! Moreover of the questions in the form of MCQ are available for each case.

This book will initially interest the radiologists for bone and joint, but also the orthopedists who will find in a ludic way of the information for still better reading the examinations than they ask for their patients.

\section{Compliance with ethical standards}

Conflict of interest The authors declare that they have no competing interests. 